\title{
Economic Implications for Stationary Trade Under the Influence of SARS-CoV-2
}

\author{
Thomas Stoyke \\ info@faust-media.com \\ Hungarian University of Agriculture and Life Sciences - Kaposvár Campus, \\ Kaposvár, Hungary \\ Uwe Radtke \\ weu@gmx.de \\ Hungarian University of Agriculture and Life Sciences - Kaposvár Campus, \\ Kaposvár, Hungary \\ https://doi.org/10.51137/ijarbm.2021.2.2.1
}

\begin{abstract}
An impact analysis against the backdrop of the Covid-19 pandemic on brick-and-mortar retail and consequences for stationary trade, with a focus on Germany. The Covid-19 pandemic has put tremendous pressure on the retail sector. Across the entire breadth of the market, significant declines in sales have already been observed, particularly in the assortments relevant to city centers, as a result of the 1st lockdown in March and April 2020 and the subsequent restrictions (accessibility of stores, masking requirements, spacing, etc.). However, delayed effects as well as the effects of the 2 nd lockdown imposed from mid-December 2020 in conjunction with the Christmas and spring business in 2021, which will be cancelled to a large extent for the stationary trade, will further exacerbate the situation in the german economy (stock market). This article sheds light on the current economic starting point, carries out a scientific, but also in particular practice-oriented, literature research of renowned business enterprises, and is intended to offer future trends and action implications from the crisis.
\end{abstract}

Keywords - Stationary Trade, Retail, Crisis, SARS-CoV-2, Implications

\section{Introduction}

„The global effects of the SARS-CoV-2 pandemic are hitting all economies hard and highlighting the weaknesses of the interconnected world" (Mohammed 2020). Despite all the normalization of everyday life and the acceptance of a so-called "new normal," this also applies to the German economy. Even if the perceived mood currently seems to be better than the actual reality, the continuing and rising infection rates in the fourth quarter of 2020 document a permanent burden, with the time extension of the lockdown to the first and second quarter of 2021.

With these framework conditions, the following article is intended to present a picture of reality and shed light on the question of:

What implications in stationary retail branches and deriving correlation can be expected under the influence of SARS-CoV-2? 
Governments around the world have taken unprecedented steps to help rescue companies and entire economies - and yet Germany's gross domestic product fell by $10.1 \%$ from April to June 2020 compared with the previous quarter (Bocksch 2020; Statistisches Bundesamt 2020). In all likelihood, the measures and efforts will have to continue for several years to be able to contain the health, social and economic effects of the pandemic (Baldwin and Di Weder Mauro 2020). A purely regional view of individual countries is misleading in this respect, as the closely interconnected global economy has considerable influences and interactions regarding the international upswing but also the downturn (McKibbin and Fernando 2020).

The German economic sectors are asymmetrically affected by the pandemic. While the tourism, event management, hotel and catering sectors, for example, are exposed to a considerable threat to their existence, as is a large part of the stationary trade, the mechanical engineering and construction sectors are affected with a time lag. This trend will also continue (Börsch-Supan and Rausch Johannes) in secondary sectors such as the German pension insurance. Online retail, medical technology, food and furniture, on the other hand, are the first "winners" of the crisis.

\section{Literature Review}

The literature review used here deals with the economic challenge of the stationary trade, caused by the Corona Pandemic in 2020 and 2021, as well as with economic expertises of recognized business companies.

Table 1: Initial results of the literature search

\begin{tabular}{|c|c|c|c|c|}
\hline Search Term & $\begin{array}{l}\text { Science } \\
\text { Direct }\end{array}$ & $\begin{array}{l}\text { Google } \\
\text { Scholar }\end{array}$ & PubMed & $\begin{array}{c}\text { Results after } \\
\text { removing du- } \\
\text { plicates }\end{array}$ \\
\hline $\begin{array}{l}\text { Stationary trade AND } \\
\text { covid IN YEAR 2021 }\end{array}$ & 167 & 933 & 167 & 881 \\
\hline
\end{tabular}

\section{Material and Method}

Stationary retail has already been undergoing structural change for several years. "Innovative online providers are attacking established business concepts and securing ever larger shares of sales. The online channel advantages are relevant for many customers and they can no longer be imagined without them" (Haug 2013). This disruptive process has accelerated and become irreversible under the current conditions, as was thematized within the 12th Retail Real Estate Summit on September 28.-29., 2020.

The winners and losers of recent years can be identified in different ways. Whereas in the 1980s and 1990s German food retailers focused primarily on size, low prices and a correspondingly plain ambience in their stores, a rethink set in with the upturn in 2006/2007 (Nierhaus 2006). Among other 
things, the reworking of the point of sale, higher-value products (Adler and Wohllebe 2020), more convenience, innovation and quality were prioritized. Likewise, discounters followed this trend. Between 2008 and 2019, sales in the sector increased by $32 \%$, according to retail expert Manuel Jahn (ACROSS | The European Placemaking Magazine 2020). Parts of the nonfood retail sector, such as the fashion industry, on the other hand, have been increasingly affected by store closures, especially in 2017. Corresponding distribution channels, such as department stores with their high fashion share and many shopping centers with their classic tenants from the sector, are following this degressive market trend. In these sectors, the pressure on rents is growing enormously. According to Jahn's estimate, the apparel sector could lose about a third of its sales by 2030. This would free up retail space - on upper floors - that would have to be rented elsewhere. This could allow other sectors, such as cinemas or cabaret, to return to the city centers and bring about a more diverse sector mix (Matkins 2021).

However, digitization with omnipresent e-commerce and almost full product availability with ever shorter delivery times with the objective of "same day delivery" will further accelerate structural change, cause downtown areas to suffer in terms of vitality, and further erode market acceptance of stationary retail.

Changing market conditions and constantly changing customer preferences make it more difficult to address and retain customers in the long term. This is also driving competitive dynamics. Around 84 percent of Britons have bought a product online in the last twelve months. No other country surveyed can boast such a high e-commerce penetration rate. The USA has a rate of around 77 percent, and in Germany it is estimated that just under three quarters of the population made a purchase online last year (Bocksch 2020).

The coronavirus pandemic is an essential threat to the established strength of brick-and-mortar retail and strategic experiential shopping (OECD 2020). Politically imposed measures, such as hygiene concepts, partial lockdowns and various forms of contact reduction are essential to contain the pandemic and, most importantly, save lives.

\subsection{Hypothesis}

In the wake of the coronavirus and its impact on the stationary trade, the following three hypotheses emerge.

A. There are mostly equal general trend developments, progressive and degressive, between textile retail, retail in total as well as the German stock market.

B. The lockdown can be seen significantly in the trend movements.

C. Internet sales have a negative impact on textile retail. 


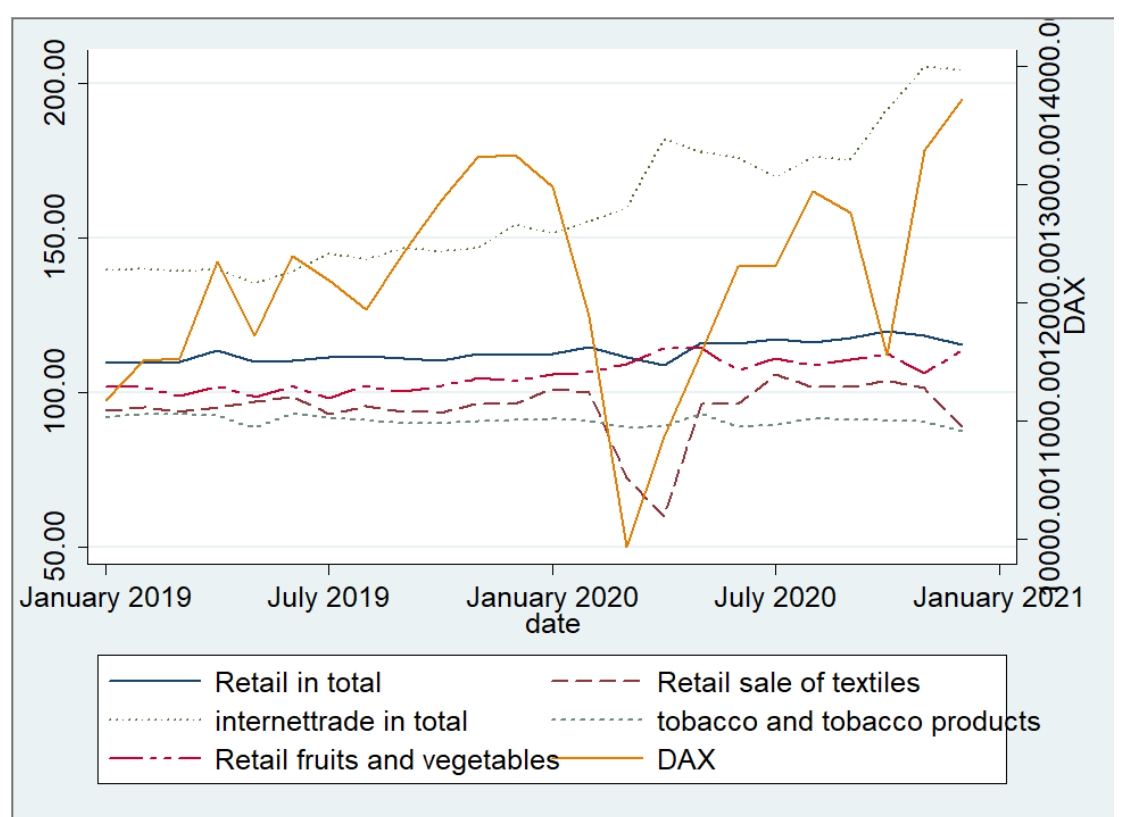

Figure 1: Detailed analysis during Covid-19 situation

The line chart represents how retail and sales of selected retail types change compared to the DAX. The $\mathrm{x}$-axis is divided into the years from 2019 to 2021. The $y$-axis shows the sales in fifty thousand increments and the DAX value.

The graphs of retail in total, retail sale of textiles, retail fruits and vegetables, tabacco and tabacco products and the internettrade in total remained largely constant until 2020. The DAX was subject to slight trading-related fluctuations during this period. With the collapse of the DAX in March 2020, retail sales of textiles also collapsed significantly at the same time. The retail in total, retail fruits and vegetables and the tabacco and tabacco products remain largely unchanged. On the other hand, internettrading slightly increased from March 2020. From the middle of the year 2020, the DAX and the retail sales of textiles rose again to the normal level. The turnover of internet trade has continued to rise slightly since then.

The reason for the collapse in March 2020 was the lockdown due to the corona crisis. 


\subsection{Research and Methology}

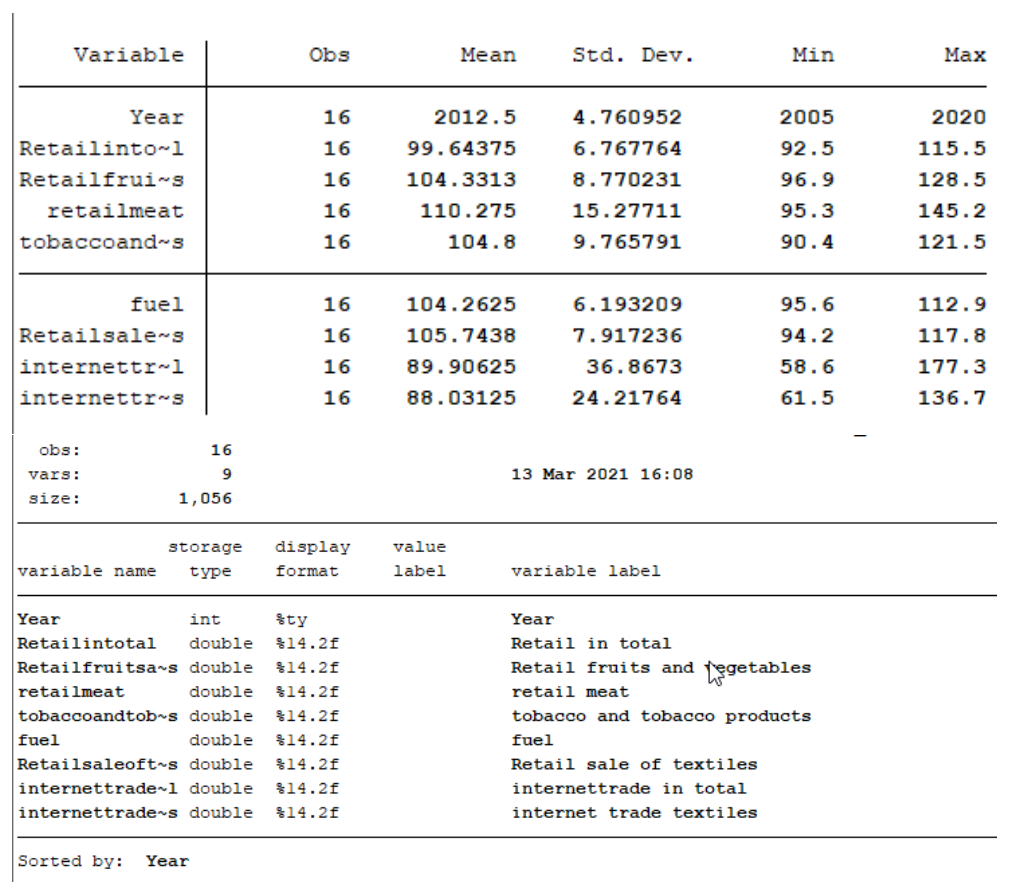

Figure 2: General data analysis (Statistisches Bundesamt 2021)

The data was already seasonally adjusted by the data providers. The year 2015 was the base with the value of 100 . A time trend is included as yearly values were used.

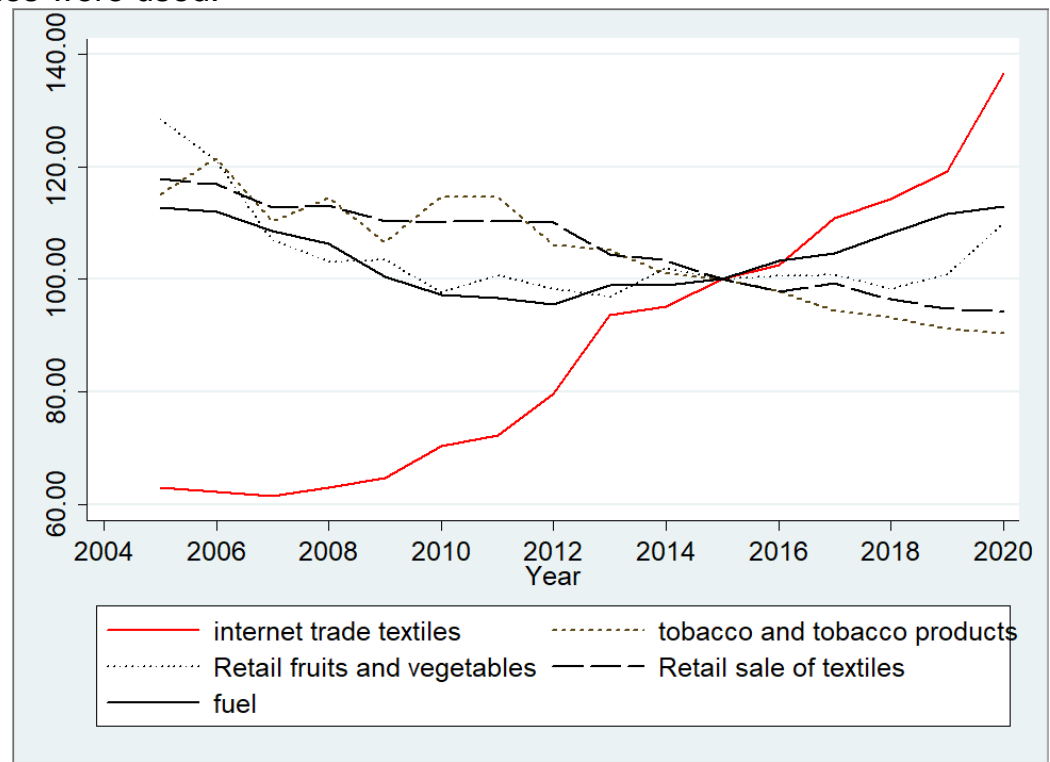

Figure 3: Detailed analysis during Covid-19 situation 
The line chart represents retail and sales of selected retail types. The $x$ axis is divided into the years from 2004 to 2020 . The $y$-axis shows the sales in twenty thousand steps.

The graphs of retail fruits and vegetables, fuel, tabacco and tabacco products and retail sale of textiles decreased slightly in the period under consideration from 2004 to 2020. A stagnation or negative trend can be seen in 2008 and 2009 in connection with the financial crisis. In contrast, the turnover of internet trade textiles has increased significantly since 2004 to over 130,000 in 2020. The Lehmann Brothers crisis did not affect the trade of textiles via internet.

The chart shows how internet trade is becoming increasingly important.

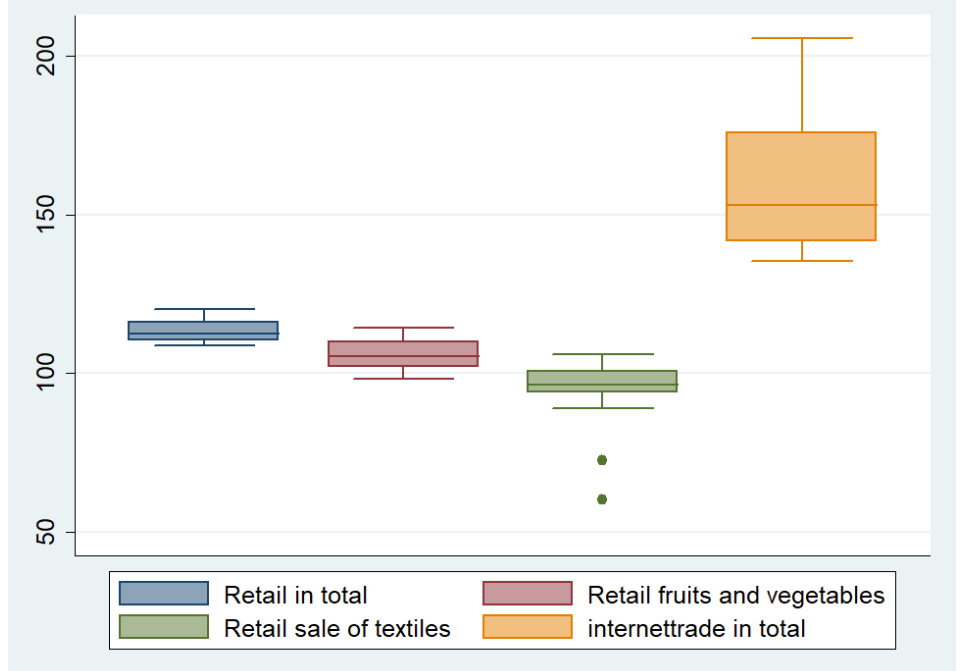

Figure 4: Boxplot, Analysis of the Retail during Covid-situation

For textile retail two outliers can be determined. Those are not exactly outliers but rather mark the month for which a "Lock-Down" was issued by the government.

\section{$4 \quad$ Results}

For the results - a time trend is included, so only unit root was tested. As a unit root was observed, the lagged versions of Retailintotal, Retailsaleoftextiles, internettradeintotal and DAX were used for further statements.

Taking all selected retail areas into consideration, the following regression is calculated: 
- reg d_retail_textiles dretail_total d_internet_trade d_DAX fuel tobaccoandtobaccoproducts retailmeat date

\begin{tabular}{|c|c|c|c|c|c|c|c|c|}
\hline Source & ss & df & & & Numbe & $x$ of obs $=$ & 23 & \\
\hline Model & 1908.97068 & 7 & 272.7 & 0097 & $\begin{array}{l}\text { F( } \\
\text { Prob }\end{array}$ & $F^{15)}=$ & $\begin{array}{r}=5.94 \\
=0.0019\end{array}$ & \\
\hline Residual & 688.301524 & 15 & 45.88 & 7683 & $R-s q$ & ared & $=0.7350$ & \\
\hline & & & & & Adj & -squared $=$ & $=0.6113$ & \\
\hline Total & 2597.27221 & 22 & 118.0 & 7828 & Root & & 6.774 & \\
\hline d_ret & 1_textiles & & Coef. & Std. Err. & $t$ & $P>|t|$ & [95: Conf. & Interval] \\
\hline & tail_total & 2.6 & 683733 & 1.005887 & 2.67 & 0.018 & .5397354 & 4.82773 \\
\hline d_in & rnet_trade & -.5 & 582715 & .2707774 & -2.15 & 0.048 & -1.159863 & -.0055667 \\
\hline & d_DAX & .00 & 040848 & .0019871 & 2.06 & 0.058 & -.0001506 & .0083203 \\
\hline & fuel & -1 . & .22352 & 1.314251 & -0.93 & 0.367 & -4.024779 & 1.5777 \\
\hline tobaccoandtob & coproducts & 1.0 & 051121 & 1.881256 & 0.56 & 0.585 & -2.958681 & 5.060923 \\
\hline & retailmeat & & 225656 & 1.106275 & 0.47 & 0.643 & -1.835404 & 2.880535 \\
\hline & date & .51 & 134459 & .568819 & 0.90 & 0.381 & -.698963 & 1.725855 \\
\hline & _cons & -377 & 7.9084 & 550.2224 & -0.69 & 0.503 & -1550.68 & 94.8629 \\
\hline
\end{tabular}

Figure 5: Figure of selected retail areas

As the tobacco products, fuel, meat sales and fruit and vegetable sales have no significant influence on the sales of textiles and general trends can be stated, these parameters are omitted on the equation. So Hypothesis $A$ can be supported, there are mostly equal general trend developments, progressive and degressive, between textile retail, retail in total as well as the German stock market

According to a simple OLS regression $\left(Y_{i}=\beta_{0}+\beta_{1} x_{1}+\beta_{2} x_{2}+\ldots+u=\right.$

With the retail sale of volume of testile as independent variable and internettradeintotal, Retailintotal and DAX as dependent variables, the following values were calculated:

- reg d_retail_textiles d_internet_trade dretail_total d_DAX date

\begin{tabular}{r|crc} 
Source & SS & df & MS \\
\hline $\begin{array}{r}\text { Model } \\
\text { Residual }\end{array}$ & 1863.48278 & 4 & 465.870695 \\
\hline Total & 2597.2789427 & 18 & 40.7660793 \\
\hline
\end{tabular}

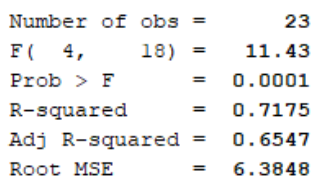

\begin{tabular}{r|rrrrrr}
\hline d_retail_texti s & Coef. & Std. Err. & $t$ & P $>|t|$ & [95\% Conf. Interval] \\
\hline d_internet_trade & -.4530712 & .2106457 & -2.15 & 0.045 & -.8956213 & -.0105211 \\
dretail_total & 2.99619 & .5648347 & 5.30 & 0.000 & 1.809517 & 4.182864 \\
d_DAX & .0036814 & .0017186 & 2.14 & 0.046 & .0000708 & .007292 \\
date & .0756573 & .2090802 & 0.36 & 0.722 & -.3636038 & .5149184 \\
_cons & -54.55745 & 150.3763 & -0.36 & 0.721 & -370.4863 & 261.3714 \\
\hline
\end{tabular}

Figure 6: Figure of selected retail areas and DAX

This reveals the internet trade has a significant negative impact (at $5 \%$ significance level) on the textile retail. The same holds true for the DAX and the retail in total - but both have a positive impact (also at $5 \%$ significance level). The later was to be expected, the huge negative impact of internet trade on textile sales was a bit surprising. This supports hypothesis $\mathrm{C}$, internet sales have a negative impact on textile retail.

For cross checking purpose a similar regression was run on the fuel price development during the 2019 and 2020 pandemic month. The outcome is almost as expected: 


\begin{tabular}{|c|c|c|c|c|c|c|c|c|c|}
\hline Source & & ss & df & MS & & \multirow{2}{*}{\multicolumn{2}{|c|}{$\begin{array}{l}\text { Number of obs } \\
\text { F }(4, \quad 18) \\
\text { Prob }>\text { F }\end{array}$}} & \multirow{2}{*}{\multicolumn{2}{|c|}{$\begin{array}{lr}= & 23 \\
= & 2.70 \\
= & 0.0637\end{array}$}} \\
\hline Model & \multicolumn{2}{|c|}{23.0230331} & 4 & 5.75575827 & & & & & \\
\hline Residual & \multicolumn{2}{|c|}{38.3760973} & 18 & 2.13200541 & & \multirow{3}{*}{\multicolumn{2}{|c|}{$\begin{array}{l}\text { R-squared } \\
\text { Adj R-squared } \\
\text { Root MSE }\end{array}$}} & $=0$ & 0.3750 \\
\hline & \multirow{2}{*}{\multicolumn{2}{|c|}{61.3991304}} & & & & & & $a=0$ & 0.2361 \\
\hline Total & & & 22 & 2.79086957 & & & & $=1$ & 1.4601 \\
\hline \multicolumn{2}{|c|}{ fuel } & \multicolumn{2}{|c|}{ Coef. } & Std. Err. & t & $P>|t|$ & {$[95 \%$} & Conf. & - Interval] \\
\hline \multicolumn{2}{|c|}{ d_DAX } & \multicolumn{2}{|c|}{.0002421} & .0004206 & 0.58 & 0.572 & -.00064 & 5416 & .0011258 \\
\hline \multirow{2}{*}{\multicolumn{2}{|c|}{$\begin{array}{l}\text { d_internet_trade } \\
\text { d_retail_textiles }\end{array}$}} & \multicolumn{2}{|c|}{-.0750589} & .0525557 & -1.43 & 0.170 & -.18547 & 1745 & .0353566 \\
\hline & & \multicolumn{2}{|c|}{.0230095} & .0336678 & 0.68 & 0.503 & -.04772 & 7239 & .0937429 \\
\hline \multicolumn{2}{|c|}{ date } & \multirow{2}{*}{\multicolumn{2}{|c|}{$\begin{array}{l}.1343795 \\
15.81481\end{array}$}} & .0479168 & 2.80 & 0.012 & .03371 & 1101 & .2350488 \\
\hline \multicolumn{2}{|c|}{ cons } & & & 34.46147 & 0.46 & 0.652 & -56.586 & 3606 & 88.21567 \\
\hline
\end{tabular}

Figure 7: Figure of selected retail areas and DAX

Unlike the sales of textiles, the fuel price is not affected by the German stock market or the internet trade.

The upward trend of internet sales was already started several years ago. A separate research would have to be performed on the reasons and starting year. It can be assumed with the usage of smartphones and the rise of global players such as PayPal and Amazon, the internet trade was fueled. Surprisingly the sales of fruits and vegetables also rose during the Lockdown starting month - again a separate research would be needed to reveal further details.

\begin{tabular}{r|rrrrr} 
Variable & Obs & Mean & Std. Dev. & Min & Max \\
\hline mdatel & 0 & & & & \\
mdate & 0 & & & & \\
Retailinto 1 & 24 & 113.1583 & 3.260157 & 108.7 & 120 \\
Retailfrui $\sim$ s & 24 & 105.65 & 5.131488 & 98.2 & 114.3 \\
retailmeat & 24 & 97 & 2.550874 & 91.7 & 101.1 \\
\hline tobaccoand s & 24 & 90.80833 & 1.589891 & 87.6 & 93.2 \\
fuel & 24 & 112.275 & 1.71039 & 108 & 114.9 \\
Retailsale s & 24 & 94.65 & 9.781793 & 60 & 105.9 \\
internettr 1 & 24 & 159.9625 & 21.44867 & 135.3 & 205.5 \\
DAX & 24 & 12197.77 & 879.9325 & 9935.84 & 13718.8 \\
\hline date & 24 & 719.5 & 7.071068 & 708 & 731
\end{tabular}

Figure 8: Figure of retail sectors and DAX

In general all hypothesizes were true and proven by the provided figures. Although not expected, the internet sales have a big stake on the retail business. Some areas were not affected by the pandemic Lockdown but simply followed an already stared downward trend. A similar downward was found for textile retail over the years already. 


\section{Outlook and Summary}

In order to contain the rapid spread of the coronavirus in Germany since late summer, a politically ordered "breakwater shutdown" was being implemented, with an extension option still open in November 2020. This severely restricts the catering and event industry in its business activities. In particular, overnight stays, indoor catering and events are prohibited. Among other things, the current increased 7-day incidence of more than 25 cases per 100,000 inhabitants is now present in 371 of a total of 401 counties. Of these, 113 urban or rural districts even have an incidence of more than 100 cases per 100,000 inhabitants. (Robert Koch Institute 2020) In this respect, the hard lockdown was decided in December 2020 and for the first and second quarter of 2021, with further negatively intensifying economic interactions for the gastronomy, trade and other industries. Above all, negative effects on the demand side result directly from domestic economic processes, in that "social consumption" is now massively restricted, in particular through strict contact restrictions of the regulations. These include restaurant visits, domestic tourism, attendance at cultural events, trade fairs, etc. (Wren-Lewis 2021). Across Germany, cultural institutions, pubs and clubs have been closed. A particular problem for this drop in demand is that it is not necessarily possible to expect catch-up effects over time. In the case of interrupted supply chains, it can be expected in many cases that the corresponding purchases and sales will take place later. If a car cannot be produced and sold today, it may be in a few months. This is different for social consumption. Restaurant visits or private trips that do not take place today will not necessarily be made up for later. Private consumption has so far proved to be a pillar of the economy. Due to the cancellation of trade shows, trips and events, a consumption recession has become very likely in 2020. In addition to the industrial recession that has already been going on for several quarters. Whether full compensation for these effects in subsequent quarters appears realistic is at least questionable, as certain demand components will not necessarily be made up.

Until SARS-CoV-2, COVID-19, possible sequelae, or even therapeutic and preventive measures are researched, the situation remains critical and the world burdened by the pandemic (World Health Organization 2020).

The future of stationary trade with the decisive differentiating feature of experience shopping with event companies seems to have no possibility of being exercised until further notice. Politics, economy and society will have to represent and live these newer framework conditions in the future, conditioned by containment measures of the pandemic.

This pandemic can only be tackled jointly and with solidarity. The light lockdown and the subsequent hard lockdown in mid-December 2020 until the first half of 2021 will once again pose considerable challenges to the economic resilience of the heavily affected sectors such as gastronomy, retail and other industries. In this respect, the government measures must be selected and implemented with extreme strength and precision in terms of timing, targeting and timing in order to prevent an economic insolvency spiral (Gaspar and Mauro 2021). 
Immediately, the situation regarding the Corona crisis is changing in a highly dynamic way and may be containable in the future with the hope of a vaccine and what is happening can be controlled.

The present text will therefore in parts be overtaken by reality at the time of publication, but should be understood until possible herd immunity is reached for a common and solidary solution of all challenges, in constructive cooperation.

\section{References}

ACROSS | The European Placemaking Magazine. (2020). 12th German

Retail Real Estate Summit /// September 28-29, 2020 /// Van der Valk

Airporthotel Düsseldorf, Germany - ACROSS / The European Placemak-

ing Magazine. https://www.across-magazine.com/12th-german-retail-realestate-summit-march-25-26-2020-van-der-valk-airporthotel-dusseldorf-

germany-2/

Adler, M., \& Wohllebe, A. (2020). Consumers Choosing Retailers On Online Marketplaces: How Can Retailers Differentiate Apart From The Price? An Exploratory Investigation. International Journal of Applied Research in Business and Management, 1(1), 27-36.

https://doi.org/10.51137/ijarbm.2020.1.1.3

AlarmstufeRot e.V. i.G. (2021, January 16). Deutschlands sechstgrößter Wirtschaftszweig steht vor dem Kollaps. https://www.alarmstuferot.org/fakten

Baldwin, R., \& Di Weder Mauro, b. (2020). Economics in the time of COVID19: A new eBook / VOX, CEPR Policy Portal. https://voxeu.org/system/files/epublication/COVID-19.pdf

Berens, S. (2014). Stationärer Einzelhandel Deutschland 2014. EHI Retail Institute. 
Bocksch, R. (2020). Volkssport Online-Shopping: E-Commerce in

Deutschland. https://de.statista.com/infografik/23865/e-commercepenetration-in-ausgewaehlten-laendern/

Börsch-Supan, A., \& Rausch Johannes. Coronavirus Pandemic: Effects on Statutory Pension Insurance | Publication | ifo Institute, 73(04), 36-43. https://www.ifo.de/en/publikationen/2020/article-journal/coronaviruspandemic-effects-statutory-pension-insurance

EHI Retail Institute, Hahn Group. Trends im Handel 2025.

https://de.statista.com/infografik/23865/e-commerce-penetration-inausgewaehlten-laendern/

Gaspar, V., \& Mauro, P. (2021, January 16). Fiscal Policies to Protect People During the Coronavirus Outbreak. imf blogs. https://blogs.imf.org/2020/03/05/fiscal-policies-to-protect-people-duringthe-coronavirus-outbreak/

Haug, K. (2013). Digitale Potenziale für den stationären Handel durch Empfehlungsprozesse, lokale Relevanz und mobile Geräte (SoLoMo). In G. Heinemann, K. Haug, \& M. Gehrckens (Eds.), Digitalisierung des Handels mit ePace (pp. 27-50). Springer Fachmedien Wiesbaden. https://doi.org/10.1007/978-3-658-01300-4_2

Heinemann, G., Haug, K., \& Gehrckens, M. (Eds.). (2013). Digitalisierung des Handels mit ePace. Springer Fachmedien Wiesbaden. https://doi.org/10.1007/978-3-658-01300-4

Lee, E. C., Wada, N. I., Grabowski, M. K., Gurley, E. S., \& Lessler, J. (2020). The engines of SARS-CoV-2 spread. Science (New York, N.Y.), 370(6515), 406-407. https://doi.org/10.1126/science.abd8755 
Li, R., Pei, S., Chen, B., Song, Y., Zhang, T., Yang, W., \& Shaman, J. (2020). Substantial undocumented infection facilitates the rapid dissemination of novel coronavirus (SARS-CoV-2). Science (New York, N.Y.), 368(6490), 489-493. https://doi.org/10.1126/science.abb3221

Matkins, A. (2021, January 16). Recession Furthers Retail Market's Dramatic Industry Shift. https://www.allenmatkins.com/anderson-forecast/summer2020-retail-q-and-a.html

McKibbin, W. J., \& Fernando, R. (2020). The Global Macroeconomic Impacts of COVID-19: Seven Scenarios. SSRN Electronic Journal. Advance online publication. https://doi.org/10.2139/ssrn.3547729

Mohammed, A. J. (2020, May 4). COVID-19 legt globale Schwächen und Ungleichheiten offen, so die stellvertretende UN-Generalsekretärin. United Nations. https://unric.org/de/04052020-covid-19-legt-globaleschwaechen-ungleichheiten-offen/

Nierhaus, W. (2006). Deutschlandprognose 2006/2007: Aufschwung geht weiter. Ifo Institut Für Wirtschaftsforschung, 13(04), 24-32. https://de.statista.com/infografik/23865/e-commerce-penetration-inausgewaehlten-laendern/

OECD. (2020, November 24). COVID-19 and the retail sector: impact and policy responses. http://www.oecd.org/coronavirus/policyresponses/covid-19-and-the-retail-sector-impact-and-policy-responses$371 \mathrm{~d} 7599 /$

Robert Koch Institute. Coronavirus Disease 2019 (COVID-19) Daily Situation Report of the Robert Koch Institute. 
https://www.rki.de/DE/Content/InfAZ/N/Neuartiges_Coronavirus/Situation sberichte/Okt_2020/2020-10-27-en.pdf?__blob=publicationFile

Statistisches Bundesamt. (2020, July 30). Bruttoinlandsprodukt im 2. Quartal 2020 um 10,1 \% niedriger als im Vorquartal. https://www.destatis.de/DE/Presse/Pressemitteilungen/2020/07/PD20_28 7_811.html

Stelter, D. (2021, January 16). Keine Rückkehr zum Trend-wachs-tum nach Corona. https://think-beyondtheobvious.com/stelters-lektuere/keinerueckkehr-zum-trendwachstum-nach-corona/

Robert Koch Institut. (2020 November 01) rki.de/DE/Home/homepage_node.html

World Health Organization (2020). Report of the WHO-China Joint Mission on Coronavirus Disease $2019 \quad$ (COVID-19). https://www.who.int/docs/default-source/coronaviruse/who-china-jointmission-on-covid-19-final-report.pdf

Wren-Lewis, S. (2021, January 14). mainly macro: The economic effects of a pandemic. https://mainlymacro.blogspot.com/2020/03/the-economiceffects-of-pandemic.html 